ISSN, 0853-8980

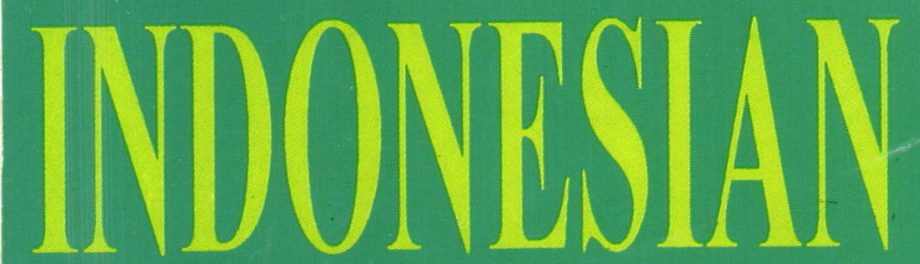

PISHERIES

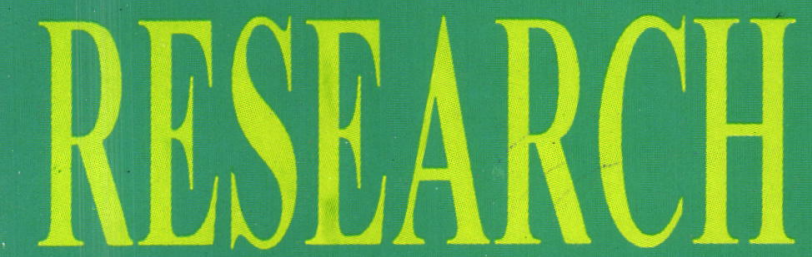

JOURNAL

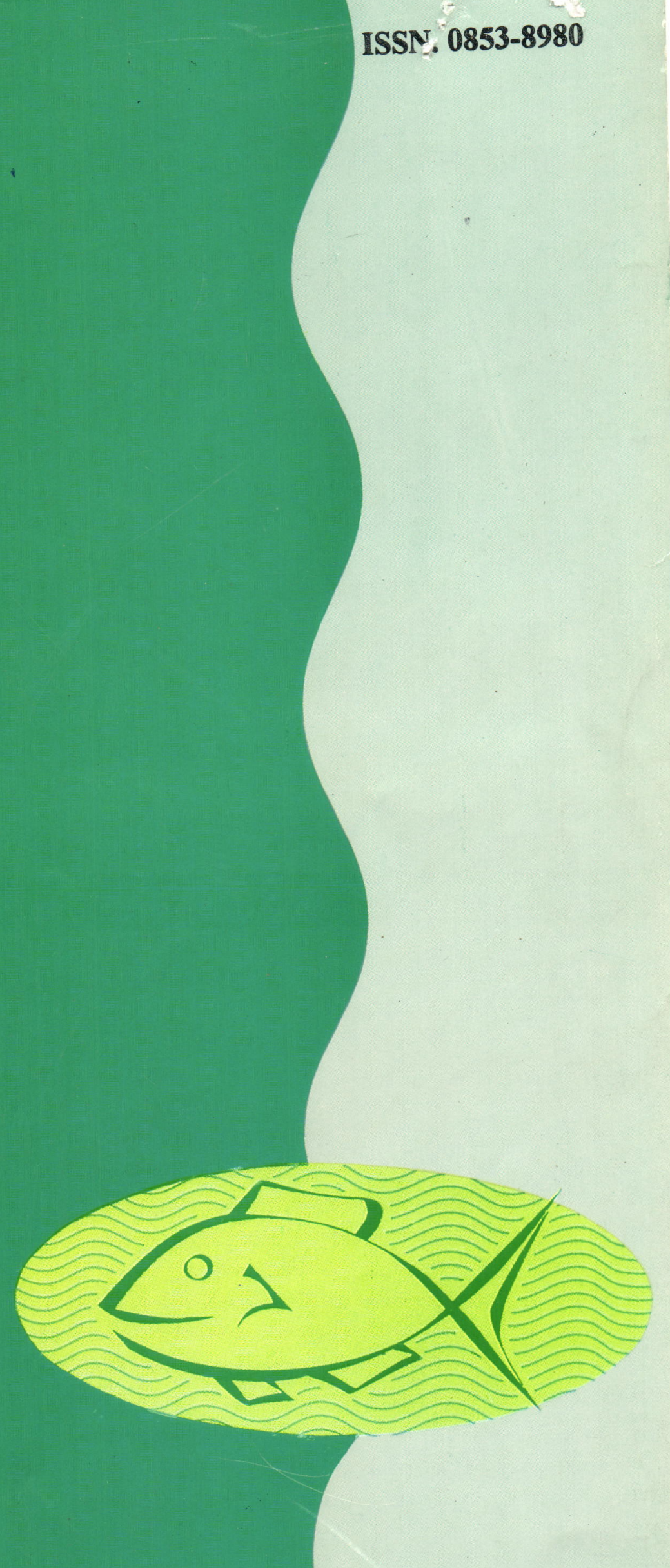
CENTRAL RESEARCH INSTITUTE FOR FISHERIES AGENCY FOR AGRICULTURAL RESEARCH AND DEVELOPMENT MINISTRY OF AGRICULTURE-REPUBLIC OF INDONESIA

Vol. V N6. 1, 1999

*

4 


\section{O N T E N T S}

The Influence of Water Hardness and Dietary Calcium on Growth and Survival of Postlarval Prawn, Macrobrachium rosenbergii

Genetic Variation in Cultured Stocks of Tiger Shrimp (Penaeus monodon) in Indonesia By: Imron, Ketut Sugama, Komar Sumantadinata, and Kadarwan Soewardi

Reproduction of Three Colour Varieties of Angelfish (Pterophyllum scalare)

By: Darti Satyani

Genetic Color Polymorphisms on Common Carp Stocks in Indonesia

By: Rudhy Gustiano

Genetic Variation and Population Structure in the Humpback Grouper, Cromileptes altivelis, throughout its Range in Indonesian Waters

By: Ketut Sugama, Tridjoko, Haryanti, Sari Budi Moria, and Fuad Cholik

The Mini Seiner Fleet of the North Java Coast: A Case Study of Their Fishing Activities By: J.M. Ecoutin and Dharmadi

Trends in Tuna Landings by the Longline Fishery Operating Out on Benoa, Bali By: T.L.O. Davis, Sofri Bahar, Nurzali Naamin, J.H. Farley, and D. Le

Fractionation of Proteases from Cowtail Ray (Trygon sephen) Viscera Using Polyacrylic Acids

By: Achmad Poernomo 